\title{
FOKUS OP DIE NED GEREF KERK BINNE DIE EKUMENIESE TONEEL IN SUID-AFRIKA
}

\author{
A G S GOUS
}

\section{ABSTRACT}

Firstly, reasons are given why the unity of the church is important. Then follows a brief historical overview of the ecumenical involvement of the Dutch Reformed Church of South Africa. Despite a good track record through the years, the 1960 s witnessed a growing tendency towards isolation supported from within and outside the DRC. With reference to the present situation the author regards the 1986 DRC policy document "Church and Society" as an ecumenical tuming-point with reference to (1) formal, (2) informal, and (3) local ecumenical relations. Attention is given to (1) models for unity of the DRC family, (2) mutual relations between the three Afrikaans churches, and also (3) the relationship with the SACC. The importance of informal and local ecumenism is also stressed. The author closes with twenty critical statements in an attempt to show a way forward for the DRC. He concludes: "If the Christians in South Africa can come to terms with one another, it will be a tremendous challenge to Christians elsewhere and a witness to the world."

Dat die eenheid van die kerk nie 'n bysaak is nie, maar' $n$ noodsaaklikheid, blyk duidelik uit die Skrif en belydenis. Die Skrif is deurspek met eenheidsbeelde van die kerk: Die een kudde met een Herder (Joh 10:16), die liggaam van Christus (1 Kor 12:12-13, Ef 4:12, Rom 12:4-5); die gelowiges as die gebou van God (1 Kor 3:16) en 'n geestelike huis (1 Pet 2:4-9); die bruid van Christus (2 Kor 11:1 ev) en een soos die Vader en die Seun een is (Joh 17:21). Ook die belydenisskrifte wat die Ned Geref Kerk ondersknyf en die ekumeniese belydenisse stel dit ondubbelsinnig: "Ons glo aan een, heilige, algemene kerk ..." (NGB art. 27; HK antw. 54 \& 55; Die Twaalf Artikels no. 9; die Geloofsbelydenis van Nicea).

Eenheid is dus tesame met die heiligheid, algemeenheid en katolisireit 'n wesenskenmerk van die kerk. Die kerk is heilig, maar moet al meer heilig word. So cok staan die kerk onder die INDIKATIEF van die gegewe eenheid in Christus maar ook onder die IMPERATIEF om die eenheid sigbaar te demonstreer en gestalte te gee.

Die feit dat die eenheid van die kerk 'n noodsaaklikheid is, bring egter nog nie 'n antwoord op die vraag hoekom die eenheid, en daarom sok die ekumeniese betrekkinge van die kerk, belangrik is nie. Volgens $\mathrm{my}$ is daar drie redes vir bogenoemde:

1. Na buite moet die kerk sy eenheid aan die wêreld toon as 'n stuk getuienis sodat die wêreld kan glo in Jesus Christus (Joh 17:2023). 
2. Na binne moet die kerk, wat bestaan uit al die gelowiges, binne die gemeenskap van die heiliges, saam soek na die waarheid. As daar' $n$ teologiese probleem opduik, word die probleem opgelos deur te gaan (1) na die Skrif en (2) na die kerk. Omdat die Bybel so misbruik word deur Christene en kerke wat net selektief op sekere Skrifwaarhede klem lê, is dit nodig dat die hele kerk (al die Christene) uitspraak moet lewer oor 'n saak.

Dit is dan ook wat gebeur het tydens die Ekumeniese Konsilies van die eerste eeue. By dié konsilies waar die hele kerk van regoor die bekende wêreld van destyds teenwoordig was, is geskilpunte opgelos deurdat die Triniteitsleer en die leer oor die twee nature van Christus geformuleer is. Binne die kerk (wêreldwyd en plaaslik) het Christene mekaar dus nodig om mekaar op die regte koers te hou. Een van die kenmerke van 'n sektariese groep is juis dat hulle nie na ander Christene wil luister nie en beweer: "Net by ons is die waarheid."

Opsommend van die eerste twee punte hierbo: Kerklike ekumene het dus 'n interne doel om saam te soek na die waarheid van Gods openbaring, asook 'n eksterne doel om gesamentlik te getuig sodat die wêreld kan glo.

3. Die derde rede waarom die eenheid van die kerk'n noodsaaklikheid is, is gewoon die opbouende ervaring van die gemeenskap van die heiliges waar "elkeen verplig is om sy gawes gewillig en met vreugde tot nut en saligheid van die ander lede aan te wend"."

In mindere of meerdere mate het die Ned Geref Kerk en ander kerke in Suid-Afrika hulle ekumeniese roeping uitgeleef. Hierdie artikel wil in breë lyne eers $(A)$ die historiese agtergrond skets, en dan $(B)$ fokus op die huidige ekumeniese toneel. Laastens (C) maak ek 'n twintigtal kritiese stellings wat as gedagtestimulante kan dien in die beoordeling van die huidige toneel met die $00 \mathrm{~g}$ op verandering. Hopelik kan dit ' $n$ beskeie bydrae lewer om meer duidelikheid te kry oor die rol van die Ned Geref Kerk vorentoe.

\section{A. HISTORIESE AGTERGROND: Hoe het die Ned Geref Kerk deur die jare aan sy ekumeniese roeping uiting gegee?}

Uit'n oorsig van die geskiedenis kan ons aflei dat die Ned Geref Kerk in die verlede 'n sterk ekumeniese visie gehad het maar dat daar tans onder sommige predikante en lidmate 'n gebrekkige ekumeniese visie bestaan. 
Sedert die vroegste jare het die Ned Geref Kerk sporadies ekumeniese kontakte onderhou. M C Vos en Van Lier kan as die ekumeniese pioniers van die agtiende eeu beskou word, toe hulle besoekende sendelinge van die Londense Sendinggenootskap broederlik ontvang het.

In die negentiende eeu was die Ned Geref Kerk ekumenies baie aktief wat interkerklike verhoudinge betref. Daar was selfs 'n poging tot kerkvereniging tussen die Ned Geref Kerk en die Anglikaanse kerk in $1870 !^{2)}$ Die Ned Geref Kerk was ook baie aktief in haar verhoudinge met sendinggenootskappe, oorsese Christelike jeugbewegings asook internasionale bonde. Andrew Murray is byvoorbeeld in 1876 benoem as die Kaapse sinode se afgevaardigde by die Presbiteriaanse Alliansie (die huidige Wêreldbond van Gereformeerde Kerke) wat in 1875 gestig is. ${ }^{3)}$

Die twintigste eeu tot en met die sestigerjare word gekenmerk deur toenemende ekumeniese aktiwiteit aan die kant van die Ned Geref Kerk. Verskeie buitelandse ekumeniese figure het die Ned Geref Kerk in dié tyd besoek, soos die besoek van John R Mott van die Internasionale Sendingraad in 1930 aan die Ned Geref Kerk van Transvaal.4) Laasgenoemde kerk was 'n stigterslid van die Wêreldraad van Kerke (WRK) in 1948. W A Visser 't Hooft, as algemene sekretaris van die WRK, het Suid-Afrika in 1952 besoek. WRK-verteenwoordigers het gedurende die laat vyftigerjare 'n aantal ekumeniese byeenkomste hier bygewoon. Die Kaapse sinode is in 1953 by die WRK geaffilieer.

Teen 1955 het die situasie ten opsigte van die Ned Geref Kerk se buitelandse ekumeniese betrekkinge so gelyk:5)

Die Kaapse en Transvaal sinodes was lid van die:

- Gereformeerde Ekumeniese Sinode (GES)

- Presbiteriaanse Alliansie later die Wêreldbond van Gereformeerde Kerke (WBGK)

- Wêreldraad van Kerke (WRK)

Die Natalse sinode was lid van die:

- Presbiteriaanse Alliansie (WBGK) en het korrespondensie gevoer met die GES.

Die Vrystaatse sinode het aan geen ekumeniese liggaam behoort nie - onder andere vanweë finansiële redes. ${ }^{6)}$

Ten opsigte van die binnelandse ekumene kan die vyftigerjare as 'n ekumeniese bloeitydperk beskou word met die Cottesloe-kerkeberaad as die laaste deel daarvan. Die Ned Geref Kerk het deel gehad aan nie min- 
der nie as sewe ekumeniese konferensies oór taal-, konfessionele en rassegrense heen. Die eerste vier is georganiseer deur die Federale Sendingraad van die Ned Geref Kerk en die res deur'n voortsettingskomitee. Die GES se 1958-sinode is in Potchefstroom gehou. ${ }^{71}$ Op die laaste van die konferensies is 'n voortsettingskomitee benoem met die doel om te werk in die rigting van ' $n$ SA Raad van Kerke wat die kerke van die Christenraad van Suid-Afrika en die Federale Sendingraad insluit. Die Ned Geref Kerk het meegewerk aan die poging. Toe kom Sharpeville ... en die Cottesloe-konsultasie volg toe die WRK sy agt lidkerke in SA gedurende Desember 1960 byeengeroep het. Die hele toneel het daarna ingrypend verander.

Sedert die sestigerjare het die Ned Geref Kerk se ekumeniese betrekkinge ' $n$ dalende lyn begin toon ${ }^{8)}$ en het die Ned Geref Kerk in sy familiebetrekkinge en ekumeniese betrekkinge stormagtige tye begin beleef. Hierdie negatiewe wending was deels die gevolg van die Sharpeville-onluste en die Cottesloe-kerkeberaad wat daarop gevolg het. Die WRK het sy Suid-Afrikaanse lidkerke byeengeroep in die Cottesloekoshuis van die Universiteit van die Witwatersrand. Dit was 'n dramatiese demonstrasie van die eenheid van die Protestantse kerke waar besluite geneem is oor onder andere gesamentlike aanbidding, gemengde huwelike en die politieke status van Kleurlinge." sewe afsonderlike Ned Geref Kerk-sinodes onder die invloed van dr Verwoerd en die Federale Raad van Ned Geref Kerke se negatiewe beoordeling van Cottesloe, die besluite wat daar geneem is, verwerp het. Die deelnemende Ned Geref-predikante is ook gerepudieer. Hierdie optrede van die sinodes was die oorsaak van die breuke wat daarna gevolg het:

1. Ernstige verwydering het ontstaan tussen die Ned Geref Kerk en die plaaslike Engelssprekende kerke.

2. Verwydering het gekom tussen die Ned Geref Kerk en Nederlandse kerke.

3. Die Christelike Instituut $(\mathrm{Cl})$ het ontstaan met $\mathrm{C} F$ Beyers-Naude as Direkteur.

4. Daar was nouer skakeling van die Nederlandse kerke met die $\mathrm{Cl}$, SARK en later ook die Belydende Kring.

Die ekumeniese betrekkinge van die Ned Geref Kerk in die twintigste eeu het egter 'n verdere kenmerk vertoon, naamlik dat spanning al hoër aan 
die oplaai was oor apartheid. Reeds so vroeg as 1939 by die wêreldjeugkonferensie te Amsterdam was die twee studenteverteenwoordigers van die Kaapse sinode al in die spervuur oor die rassekwessie en veral die segregasie in die kerk in SA. ${ }^{10}$ Sedertdien was apartheid die enkele groot faktor wat die ekumeniese gesprek oorheers het. Vir die buitewêreld was apartheid in kerk en staat die steen des aanstoots wat die ekumeniese toneel in SA ontsier het. Die Ned Geref Kerk is daarmee gekonfronteer. Hoe het dié Kerk gereageer?

"Die Ned Geref Kerk het oor die jare heen indringende gesprekke or apartheid en sy hantering van die Skrif in dié verband ontwyk, en hom of van sulke gesprekke onttrek, of skerp en onbegrypend teen kritiek gereageer. Daar is 'n sterk neiging by die Ned Geref Kerk om hom gevolglik ekumenies te isoleer."11)

Deur te onttrek aan ekumeniese forums is die spanning dus verminder, maar die probleem is nie opgelos nie. Die welkome uitsondering was die Algemene Sinode van 1986. Voor die sinode het die breë moderatuur met ds J E Potgieter as moderator, die bande met die GES opgeskort. Die sinode het hierdie optrede nie goedgekeur nie en die Ned Geref Kerk sodoende van totale isolasie op die gebied van internasionale konfessionele ekumene gered.

'n Verdere belangrike ontwikkeling op die kerklike toneel van die negentiende en twintigste eu is die konstituering van afsonderlike Ned Geref Kerke vir die verskillende bevolkingsgroepe. Die proses is afgeskop toe die Ned Geref Sendingkerk in 1881 gekonstitueer is. Dit was die logiese uiteinde van die bekende besluit van 1857 toe daar onder andere "weens die swakheid van sommige" besluit is op afsonderlike vergaderplekke vir die anderskleuriges. Die proses is voltooi in 1968 met die konstituering van die Indian Reformed Church. ${ }^{12)}$

Veral in die tweede helfte van die twintigste eeu is die goeie verhouding tussen die Ned Geref Moederkerk en die jonger Ned Geref Kerke ook vertroebel as gevolg van apartheid. Reeds in 1948 spreek die Ned Geref Sendingkerk se ring van Wynberg hom uit teen apartheid en verklaar dat daar geen skriftuurlike gronde vir apartheid bestaan nie.

Die negentiende en twintigste eeu het ook die ingewikkelde ontstaansgeskiedenis en mislukte eenheidsoeke van die drie Afrikaanse "susterkerke" aanskou.

Met bogenoemde skets as agtergrond kan ons nou die blikpunt skuif na die huidige ekumeniese toneel. Daar is aanduidings dat die 1986sinode met die aanvaarding van "Kerk en Samelewing" dalk 'n ekumeniese herstelfase ingelei het. Veral dié beleidsdokument skep nuwe moontlikhede om die ekumeniese gesprek wat vasgeval hat weer op dreef te kry. 


\section{B. DIE HUIDIGE EKUMENIESE TONEEL}

Hierdie afdeling konsentreer slegs op die formele en informele binnelandse ekumene, en laat die buitelandse ekumeniese betrekkinge buite rekening.

\section{Formele of amptelike ekumene}

As ons die Ned Geref Kerk as fokuspunt neem, kan die huidige ekumeniese toneel in Suid-Afrika beskryf word in terme van konsentriese sirkels. Hierdie konsentriese sirkels dui die relatiewe verhouding aan waarin die Ned Geref Kerk tot ander kerke en godsdienstige groeperings binne (en buite) Suid-Afrika staan:

"๘ Die binneste sirkel word gevorm deur die Familie van Ned Geref Kerke,

* die tweede word bepaal deur die drie Afrikaanse kerke,

* die derde deur die ander Protestantse kerke,

* die vierde sirkel bestaan uit die Rooms-Katolieke Kerk en die verskillende sektariese groepe, [sic - myns insiens 'n ongelukkige saamgroepering] en

* die wydste sirkel word gevorm deur die groot aantal separatistiese groepe."13)

Prof Tjaart van der Walt gebruik self die term "konsentriese sirkels" om die gemeenskap van die heiliges te beskryf. ${ }^{14)}$

Vervolgens word die kerklike verhoudinge met die familie van Ned Geref Kerke, die drie Afrikaanse kerke en die SARK bespreek.

\section{Die Ned Geref Kerk se verhouding met die NGSK, NGKA en die RCA}

Volgens die amptelike beleid van die Ned Geref Kerk vorm die verhouding met die familie van Ned Geref Kerke die binneste sirkel van kerklike verhoudings waaraan eerste aandag gegee moet word. Huidig is die kerke in 'n federale band saamgevoeg in die Federale Raad van Ned Geref Kerke.

"Kerk en Samelewing" stel dit duidelik dat die status quo onbevredigend is. Die eenheid van die Ned Geref Kerk-familie moet duideliker tot uitdrukking gebring word (par $257 \& 258$ ). Hoe hierdie sigbare eenheid daar moet uitsien sal "langs die weg van indringende samesprekings tussen die verskillende lidkerke, in die lig van die eise van die_Skrif en van 
praktiese omstandighede", uitgemaak moet word. ${ }^{15)}$

'n Aantal modelle vir sigbare kerkeenheid is in omloop en word genoem:

i. 'n Oorkoepelende sinode wat bindende besluite vir die samestellende kerke kan neem volgens die voorbeeld van die Gereformeerde Kerk in Suid-Afrika (GKSA). ${ }^{16)}$ Die federatiewe band met die buitelandse familielede word behou. Die binnelandse familielede behou elkeen hulle kerkrade, ring, sinode en nasionale sinode. Elke nasionale sinode vaardig dan verteenwoordigers af na een Algemene Sinode. Hierdie voorstel is egter in 1978 deur die Algemene Sinodes van sowel die Ned Geref Kerk as die NGSK venwerp, om min of meer die teenoorgestelde redes.

ii. In 1983 het die Algemene Sinode van die Ned Geref Kerk in Afrika eenparig "besluit om te werk in die rigting van een kerkverband vir al vier Ned Geref Kerke, met een belydenis, kerkorde, lidmaatskap, legitimasie en fondsestruktuur; daar behoort, so het die Sinode besluit, aan die hand van drie modelle in opeenvolgende fases aan kerkvereniging gewerk te word". ${ }^{17)}$

iii. Die "saamsoek"-model wil nie die presiese vorm van eenheid voorskryt nie. Saamsoek is dan die eerste demonstrasie van eenheid. "Hierdie eenheid impliseer dat eenwording binne die NGK-familie sowel op plaasiike as op breër vlak dringend gesoek moet word en dat dit sowel in die gemeenskapsbelewenis van gelowiges op gemeentelike vlak as in die breër strukture van die kerk bewerkstellig moet word om sodoende ook die bestaande isolasie te deurbreek."18)

iv. Die "belydende" kerk. Met hierdie moontlikheid wil die voorstanders daarvan die bestaande kerkstrukture omseil en slegs eenheid tussen die "ware belydende" Christene bewerkstellig. "Die gedagte hieragter is dat die Christene wat apartheid verwerp 'n belydende kring van ware Christene vorm teenoor dié in die kerke wat die valse kettery van apartheid aanhang. Die Belydende Kring moet dus die kern vorm van die toekomstige verenigde Ned Geref Kerke wat apartheid verwerp."19) 'n Groep predikante uit die NGKA en die NGSK wat hierdie gedagte steun, het in 1975 in Bloemfontein vergader en die byeenkoms aangekondig as "die eerste Algemene Sinode van die Susterskerke". Die Algemene Sinode van die NGKA in 1975 het hierdie optrede van sy leraars veroordeel. ${ }^{20)}$ Uit die 
Bloemfonteinse vergadering is die Broederkring gebore, later genoem die Belydende Kring, wat bestaan uit wit en swart lede van die NGKA, NGSK en RCA. Die Belydende Kring hou hulle in die buiteland en veral Nederland voor as die ware verteenwoordigers van die kerk alhier. As eerste stap in die rigting van 'n nuwe veelrassige Gereformeerde eenheidskerk is ABRECSA (Alliance of Black Reformed Christians in South Africa) in 1981 gestig. Die groep het veral ook voorbrand gemaak om apartheid as kettery te veroordeel tydens die WBGK se 1982-vergadering te Ottawa. Die gedagte is dus nie om eenheid met die Ned Geref Kerk te bereik nie, maar om die Ned Geref Kerk sover as moontlik op alle vlakke te isoleer. Geen dialoog mag met die Ned Geref Kerk gevoer word solank hy nog nie apartheid as sonde verwerp en sy skuld bely oor sy aandeel aan die onderdrukking en lyding van swartmense nie.

Volgens Crafford setel die kritiek teen die Belydende Kring (1) in die liefdelose karikatuur wat van die Ned Geref Kerk geteken word, (2) die polariserende uitwerking van hul optrede wat byvoorbeeld die RCA feitlik in twee laat skeur het, en (3) die teologiese uitgangspunte wat bevryding deur geweld insluit. 21) "Die NGK is egter besig om hom te bekeer van apartheidsteologie en om sy lidmate ook op die pad van bekering te probeer lei. Die vraag is of die Belydende Kring hom ook sal bekeer van sy pad van geweld en of hy homself in die afgrond sal laat meesleep in die rewolusie wat hy propageer as enigste manier om apartheid af te breek?"22)

Daar sal kreatief na hierdie modelle gekyk moet word, en nuwe moontlikhede sal oorweeg moet word. Die taak van die Ned Geref Kerk is om allereers sy familie-huis in orde te kry.

\section{Die verhouding tussen die drie Afrikaanse kerke}

"Die afsonderlike bestaan van die drie Afrikaanse kerke is prinsipieel nie te verantwoord nie. Hulle het basies dieselfde belydenis, kerkregering en liturgie; hulle is saam in dieselfde land en vervul hulle roeping onder dieselfde volk; hulle bèdieningsbehoeftes is in alle opsigte dieselfde. Daar bestaan dus geen deurslaggewende rede waarom die betrokke kerke nie tot 'n sigbare eenheid kan kom nie."23)

Hoe oordeel die drie kerke self hieroor? Van der Watt gee die volgende oorsig: ${ }^{24)}$ 


\subsection{Die GKSA}

Die standpunt van die Gereformeerde Kerk in Suid-Afrika se deputate by die Tussen-Kerklike Kommissie (TKK)-vergadering is dat die geloofseenheid tussen hierdie kerke tot sigbare uitdrukking moet kom in een kerkverband. Die sinode van 1978 aanvaar die roeping "om dit wat uitmekaar hou, broederlik onder oë te sien om sodoende in een kerkverband te bring".

Die GKSA voer egter 'n kerkregtelike rede aan, naamlik die kwessie van toesighouding oor die erediens, waarom kanselruilings nie mag plaasvind nie. Of dit 'n geregverdigde verweer is, moet bespreek word.

\subsection{NGK}

Die Ned Geref Kerk beskou die bestaan van die drie kerke as sondige verskeurdheid waarmee mens nie vrede mag hê nie. Die 1982-Algemene Sinode openbaar 'n mate van ongeduld met die stadige vordering van die TKK: "Die eerste opdrag aan die TKK bly steeds om 'n gesprek oor kerklike eenheid te voer, om vas te stel wat die kerke uitmekaar hou en voorstelle ter bevordering van kerklike eenheid te formuleer."25)

\subsection{Die NHKA}

In skerp teenstelling met bogenoemde is die standpunt van die Nederduitsch Hervormde Kerk in Afrika. Die houding oor organisatoriese kerkeenheid wissel van sterk afwysing tot uiters versigtige benadering. Die ervaring van die abortiewe kerkvereniging van 1885-1892, dra dalk daartoe by. Van der Watt haal 'n verantwoordelike kerkleier (prof A D Pont) aan wat selfs die motiewe van die ander twee kerke betwyfel: "Is die eis tot kerkvereniging nie 'n fyn poging om ons kerk (die NHKA) in 'n kerklike struktuur in te trek waar art. 3 van die Kerkwet oorstem kan word nie? Verder word hierdie beweegredes betwyfel as bedink word dat die GKSA nie predikante van die ander twee kerke op sy kansels toelaat nie en dat sommige leraars van die Ned Geref Kerk se houding teenoor die NHKA betreurenswaardig is."26)

Die NHKA verskil ook oor die "sondige verskeurdheid". "Vir die NHKA is die eenheid van die kerk geleë in die een Hoof van die kerk. Hierdie eenheid hoef nie in ' $n$ interkerklike organisasie tot uiting te kom nie."27)

Die drie Afrikaanse kerke sou dan in die lig van die geskiedenis gewoonweg histories "geword", "gegroei" het en kan nie as sondige 
verskeurdheid beskou word nie. Samewerking met die ander twee kerke is wel belangrik, maar nie kerkvereniging nie. Eenwording is iets wat nie oornag geskied nie. Dit sal moet groei, etlike jare lank - volgens die NHKA. Die Algemene Kerkvergadering van die NHKA het in 1986 besluit: "Die vergadering neem kennis van die werksaamhede van die TKK en spreek die wens uit dat die gesprek voortgesit sal word. Met betrekking tot die resultaat van die gesprek met die Susterkerke: Van die vordering [? my vraagteken] met die gesprek oor 21 jaar word met waardering kennis geneem. Die gesprek sal voortgesit word op die wyse en in die gees van die besluite van die Kerk."28)

Ek sluit af met 'n stelling van Van der Watt: "Indien die NHKA die ontstaan van die GKSA in 1859 as 'n afskeiding sien en van die Ned Geref Kerk in Transvaal se afskeiding in 1866 praat, dan mag daar tog sekerlik nie by ' $n$ afskeiding berus word nie - by sonde geld nie toleransie nie!"29)

\section{Die Ned Geref Kerk se verhouding met die SARK}

Die Christenraad, die voorloper van die Suid-Afrikaanse Raad van Kerke, is in 1936 in Bloemfontein gestig. Ds W Nicol, een van die stigterslede van die Broederbond, is verkies tot die eerste president vañ die Christenraad. $\mathrm{Hy}$ het die eerste vergadering van die Christenraad afgesluit met die woorde: "the spiritual church dare not be isolated. Isolation is death". ${ }^{30}$ ) Die Christenraad was ' $n$ assosiasie van kerke en sendinggenootskappe om daardeur die uitbreiding van die koninkryk van God te bevorder. Die betrokkenheid van die Ned Geref Kerk by die Christenraad het egter geëindig toe die gefedereerde Ned Geref Kerke in 1942 hulle eie Federale Sendingraad gestig het. Nicol het tevore bedank as president en gesê: "it grieves me to take this step. A great body, uniting the voice of Protestant Christendom in South Africa, has been my dream for years. You and I are, however, not to see it, and we can but hope that the next generation will. Possibly the Federated Missionary Council and the Christian Council might in due time set up machinery for a measure of co-operation".31)

Die vrees vir oorheersing deur die ander kerke, omdat die Ned Geref Kerk slegs 10 verteenwoordigers uit die 45 lede in die Christenraad sou hê was die belangrikste rede. Die 1935-sendingbeleid van afsonderlike kerke sou daardeur in gevaar gestel word. ${ }^{32)}$

Op die Cottesloe-beraad in Desember 1960 het die deelnemers van die agt lidkerke van die Wêreldraad van Kerke besluit om by hulle kerke aan te beveel dat ' $n$ Suid-Afrikaanse konferensie van lede van die Wêreldraad van Kerke gestig word. ${ }^{33)}$ Nadat die besluite van die Cottesloeberaad deur die onderskeie sinodes van die Afrikaanse kerke veroordeel 
is en die Ned Geref Kerke in die Kaap en Transvaal uit die Wêreldraad van Kerke uitgetree het, het daar helaas niks van dié voorstel tereggekom nie.

In 1968 het die Christenraad sy grondwet gewysig en die naam verander na die Suid-Afrikaanse Raad van Kerke (SARK).

Die Christenraad (later die SARK) het oor'n hele verskeidenheid van sake met die Breë Moderatuur van die Ned Geref Kerk in verbinding getree. Trouens, die sekretaris, Basil Brown, het die beleid gevolg om alle belangrike sake van die Raad na die Ned Geref Kerk te verwys om hulle medewerking te verkry of hulle te versoek om onafhanklik op te tree oor die betrokke saak. Hy het gemeen dat welwillendheid daardeur opgebou is, al was daar meningsverskil oor die sake. Oor geen ander saak behalwe die afkondiging van huweliksgebooie is daar egter gesamentlik opgetree nie! ${ }^{34)}$

Die SARK het in 1975 besluit om weer 'n uitnodiging aan die Ned Geref Kerk te rig "to consider with great urgency entry or re-entry into the fellowship of the Churches and Christians represented in the SACC ..."35) Uitnodigings tot lidmaatskap en pogings tot dialoog is herhaal in 1977 , 1980 en 1986. Telkens is daar afwysend gereageer deur die amptelike mening van die Ned Geref Kerk. ${ }^{36)}$ Met die sinode van 1986 het daar egter ' $n$ wending gekom toe besluit is om "informele samesprekinge met die SARK te voer ten einde ' $n$ korrekte beeld van mekaar te bekom". ${ }^{37)}$ Ten slotte wil ek aansluit by Borchardt: "Kan ons, die NGK, ten spyte van al die hindernisse (en daar is baie want daar is ook baie onvolkomenhede in die SARK), bekostig om nie met die SARK te praat nie? Watter getuienis sal 'n groot sterk liggaam van kerke in Suid-Afrika kan lewer teenoor die wêreld?"38)

\section{Informele ekumene}

Omdat die formele ekumeniese betrekkinge meermale op 'n dooiepunt uitloop was daar die afgelope jare 'n groot oplewing op die terrein van die informele ekumene. Die suksesvolle SACLA-byeenkoms in 1979 onder leiding van prof David Bosch kan hier as voorbeeld genoem word. So ook die NIV (Nasionale Inisiatief vir Versoening). Die amptelike kerkmening was huiwerig om sulke pogings te steun. Dit het egter nie verhoed dat heelwat NG-predikante deur die jare aktief deelgeneem het aan informele ekumeniese skakelgeleenthede nie - landswyd of op streeksvlak. Betrokkenheid by sodanige byeenkomste is nodig om saam te soek na die wil van God in ons situasie en te getuig vanuit jou perspektief op die waarheid. 


\section{Plaaslike ekumene}

Die ekumeniese roeping van die kerk hoort nie net tuis by die Breë Moderatuur of kerkleiding nie. Plaaslike ekumeniese uitlewing is die toets vir werklike ekumeniese betrokkenheid. Die Algemene Sinode van 1982 het erkenning gegee aan dié feit deur "die wenslikheid te aanvaar dat ekumene ook deur mindere kerkvergaderings beoefen moet word". ${ }^{39)}$ Dit is aan streeksinodes, ringe en kerkrade opgedra om ekumenies meer aktief te raak en hulle bepalinge dienooreenkomstig uit te brei.40) Dr Pierre Rossouw, Hoof- Uitvoerende Amptenaar van die kerk, steun hierdie standpunt en beweer dat ekumene tans te dikwels gesentraliseerd beoefen word. Desentralisasie is nodig deur aktiewe kommissies vir ekumeniese sake op elke kerkraad te kry. ${ }^{41)}$ Skakeling met ander kerkgenootskappe in eie omgewing kan gemeentelede bring tot beter begrip van sondige verskeurdheid en regmatige (dalk oortollige) verskeidenheid. ${ }^{42)}$ Dit kan aangevul word deurdat plaaslike predikante van verskillende kerkgenootskappe mekaar in broederkringe ontmoet. Ooreenstemmende kommissies van verskillende kerkrade (bv. jeug met jeug) kan ook met mekaar skakel. 'n Aantal gemeentes stel 'n goeie voorbeeld in dié verband, waaronder die gemeente Lynnwoodrif in Pretoria.

\section{C. 'N TWINTIGTAL KRITIESE OPMERKINGS}

'n Aantal standpunte word nou weergegee met die oog daarop om bespreking uit te lok:

1. Die eerste stelling is: Die Ned Geref Kerk se verhouding met die NGKA, NGSK en Reformed Church in Africa kan nie beskou word as ekumeniese betrekkinge nie. Veel eerder is dit familiebetrekkinge. Voorts: die feit dat die Ned Geref Kerk-familie in Suid-Afrika 'n nouer kerkverband benodig om sigbare gestalte te gee aan die eenheid van die kerk, staan vas. Hoe dit moet gebeur, moet dringend uitgeklaar en bespreek word.

2. Die Ned GerefKerk het sedert die tweede helfte van die 19de eeu op die basis van 'n liberale kerkreg begin funksioneer. ${ }^{43)}$ Tipiese kenmerke van die 19de-eeuse kerkbeskouing is:

- die ware kerk is die onsigbare kerk;

- geen probleem word voorsien as gelykgesindes eie kerke stig nie; 
- die kerk word 'n mensgemaakte collegium - 'n klub van eendersdenkendes met dieselfde belange en voorkeure;

- op grond van ondergeskikte redes (selfs onbenullige redes) word verskillende kerke gestig wat staan op dieselfde belydenis. Die drie Afrikaanse kerke is ' $n$ voorbeeld hiervan. So ook die gemaklike stigting van die afsonderlike Ned Geref Kerke. ${ }^{44}$

3. Die liberale kerkbeskouing wat van die kerk 'n groep eendersdenkendes gemaak het, het ook tot gevolg gehad dat ekumene verkeerdelik beskou word as 'n gesprek tussen eendersdenkendes. So bywoorbeeld sê dr Dirk Fourie ${ }^{45}$ ) dat dit nuttig is om ekumeniese gesprekke te voer maar op voorwaarde dat die gespreksgenote dieselfde belydenis moet hê en in die breë moet saamstem oor sake. Die kritiese vraag wat hier gestel moet word is: Wat is dan die nut van gesprek as 'n mens net saamstem oor sake? Die gegewe eenheid in Christus omvat tog ook baie verskille selfs in teologiese interpretasie.

4. As die konsentriese sirkel-konsep gebruik word om ekumeniese verhoudings te struktureer, moet die vraag gevra word: Wie is in die middel van die sirkel? Slegs as daar erken word dat Christus in die middel staan, en nie 'n enkele kerk nie, kan die konsep met vrug gebruik word. Alle kerke moet beskou word as op die rand van die sirkel om daardeur erkenning te gee aan onvolkomenheid in eie teologie.

5. Internasionaal en in die binneland sal daar onderskei moet word tussen konfessionele ekumene (GES-tipe) en interkonfessionele ekumene (WRK-tipe). Albei tipes ekumene sal aandag moet geniet. Met dit in gedagte, moet ons die vraag stel of artikel 71 van die kerkorde volledig is. Word die buitenste konsentriese sirkel van interkonfessionele ekumene nie dalk uitgelaat nie? Het ons die artikel tot dusver prinsipieel suiwer hanteer deur huidig uitsluitlik op sommige gereformeerde kerke en gereformeerde wêreldliggame te konsentreer?

6. Die ekumeniese gesprek slaag nie net as konsensus bereik word nie, maar ook as konvergensie plaasvind. Met ander woorde, as daar nader aan mekaar en nader aan die waarheid beweeg word.

7. Die herstel van buitelandse ekumeniese betrekkinge is direk afhanklik van die herstel van die Ned Geref Kerk se familiebetrekkinge.

8. Die skuld vir die breuk in ekumeniese betrekkinge lê nie net by die Ned Geref Kerk en by apartheid nie. Die mate waarin die kritici van die Ned 
Geref Kerk geradikaliseer het, sou dit vir enige kerk onmoontlik gemaak het om goeie betrekkinge te handhaaf.

9. Die Ned Geref Kerk moet weer 'n slag onbevange gaan kyk na die Belhar-belydenis van die NGSK van 1982. Dit is 'n teologiese stuk wat gegrond is op gereformeerde Skrifgebruik, wat nie dieselfde taal adem as sommige uitsprake van die Belydende Kring nie. Dieselfde geld vir die NGSK om onbevange na "Kerk en Samelewing" te kyk en die gesprek te hervat.

10. Het die NGSK nie familie-eenheid onmoontlik gemaak deur'n vierde belydenisskrif te aanvaar, naamlik deur die Belhar-belydenis tot ' $n$ belydenisskrif te verhef nie?

11. Die vraag word gevra of daar nie 'n moedswilligheid in die geledere van die Belydende Kring is nie. Die indruk word geskep dat versoening nie gesoek word nie omdat dit hulle stryd ("struggle") teen 'n "bose" teologie sal benadeel en ontlont. Is daar nie dalk ook'n ongesonde onwilligheid tot gesprek by sommige Ned Geref-kerkleiers nie? Die wyse waarop kerkleiers van albei kante met mekaar kat en muis speel deur ad hominemverklarings en uitstapaksies maak die kerk nie meer geloofwaardig in die oë van die wêreld nie.

12. As die Ned Geref Kerk gereformeerde teologie 'n oneer bewys het met ' $n$ teologiese regverdiging vir apartheid, dan bewys die Belydende Kring dit nog 'n groter oneer met sy ondersteuning van rewolusie en geweld as middele waardeur die koninRryk van God gedien mag word. As die Ned Geref Kerk met sy ondersteuning van 'n skeidingsbeleid skuld het aan die lyding van baie mense, sal die Belydende Kring skuld hê aan oneindig meer lyding as daar ' $n$ totale bloedbad in Suid-Afrika ontstaan.

13. Enige pleidooi ten gunste van die hereniging van die drie Afrikaanse kerke om enige ander rede as die gemeenskaplike geloof is ook ' $n$ manifestasie van die liberale kerkbeskouing: dit sal volgens sommige die "nut" van die Afrikanersaak dien indien hulle sou verenig - wat deur en deur'n liberaal-teologiese argument is. ${ }^{46)}$

14. Amptelike wedersydse kerklike beraadslagings is nie genoegsaam vir die herstel van gebroke gemeenskap tussen byvoorbeeld die drie Afrikaanse kerke nie: ook die plaaslike gemeente en elke lidmaat moet hiertoe opgewek word en in aanraking gebring word met die ander twee kerke. 
15. Die moontlikheid bestaan steeds - soos in die vorige eeu - dat net twee van die drie Afrikaanse kerke die pad van organisatoriese kerkeenheid mag loop.

16. Meermale is die verskeurdheid van die kerk toe te skryf aan die sondigheid en hardkoppigheid van die mens: samewerking is nie 'n hoedanigheid eie aan die menslike natuur nie - eerder dié van twis, verdeeldheid en skeiding.

17. In die ekumeniese gesprek lê die Engelse kerke meestal dieklem op die horisontale vlak van menseverhoudinge. Die Afrikaanse kerke wil daarenteen meer gesels oor kerklike lewe en leer en skram soms daarvan weg om oor rasseverhoudinge te praat. Hierdie twee beklemtonings moet mekaar egter aanvul want die waarheid bevat albei.

18. Daar is 'n geneigdheid aan die kant van die Ned Geref Kerk om net aan ekumeniese inisiatiewe binnelands deel te neem as dit deur die Ned Geref Kerk self gereël word. Die nuwe inisiatiewe en ekumeniese vergaderings wat die Ned Geref Kerk reël is egter baie positief, en kan 'n nuwe era in dié kerk se ekumeniese skakelings met ander Protestantse kerke inlei. Dit moet egter gekomplementeer word deur ook te reageer op ander uitnodigings tot deelname aan formele en informele ekumeniese byeenkomste. Hieroor sê dr Pierre Rossouw, predikant met opdrag Ekumeniese Betrekkinge: "Die Ned Geref Kerk moet meer versigtig wees om 'n reaksionêre ekumenisme te vermy, om ons soms te maklik te isoleer en die operasionele gebied aan humanistiese ekumene oor te laat."47)

19. Die opregte begeerte tot versoening tussen die SARK en die Ned Geref Kerk moet duidelik blyk en daar moet opgehou word om strategiese speletjies met mekaar te speel. Dit geld ook vir die Ned Geref Kerk se verhouding tot die NGSK. Moedswilligheid en 'n houding van onversoenbaarheid moet veroordeel word.

20. In die vyftiger-en sestigerjare was daar groot sosiale druk op teoloë en predikante wat nie die apartheidsteologie wou onderskryf nie. Tans ervaar swart en Kleurling-teoloë geweldige druk uit eie geledere as hulle nie die rewolusionêre bevrydingsteologie steun nie. (Bevrydingsteoloë ervaar ook groot druk van staatsweë.) Dit benadeel 'n onafhanklike denke oor probleem-areas omdat daar altyd oor die skouer gekyk moet word. Karaktermoord was die kenmerk van die sestigerjare - tans is werklike moord die gevaar. 


\section{DIE NED GEREF KERK SE ROL NOU EN IN DIE TOEKOMS}

Die Ned Geref Kerk sal met oorgawe moet inklim om sy deel van die deurmekaar ekumeniese huis in Suid-Afrika reg te pak. Op alle vlakke sal daar gewerk moet word.

Beginnende by teologiese opleiding sal al die Ned Geref-fakulteite hulle teologiese curriculum so moet uitbrei om meer aandag aan die vak ekumenika te wy. Huidig is ekumenika 'n onderafdeling van vakke soos Nuwe Testament, Sending, Kerkgeskiedenis, Dogmatiek en selfs Praktiese Teologie. Die antwoord lê dalk daarin om ekumenika in die toekoms tot 'n selfstandige vak te verhef. Die onkunde oor ekumenika onder predikante van ons kerk kan op dié wyse opgelos word.

Voorts sal daar van bo af gewerk moet word en die kerkleiding sal met nuwe ywer die formele ekumeniese betrekkinge moet aanpak. Die gesprek sal veral rondom drie dokumente moet draai: (1) die Belharbelydenis, (2) die Kairos-dokument, en (3) "Kerk en Samelewing".

So sal daar ook van onder af gewerk moet word met hernude ywer. Ekumeniese kommissies op kerkrade en KJA's wat sinvol funksioneer kan Christene op plaaslike vlak aanspoor tot 'n groter demonstrasie van eenheid. P G J Meiring ${ }^{48)}$ stel voor: "oor en weer besoeke; gesamentlike besprekingsgeleenthede; gesamentlike getuienis en diens; gesamentlike aanbidding veral tydens kerklike feesdae en dank en verootmoedigingsdae".

Ook sal daar van binne af gewerk moet word waar Christene en predikante informeel bande smee, om sodoende die fondament te lê vir sigbare eenheid wat die koninkryk sal dien.

Op al hierdie vlakke sal aandag gegee moet word aan elk van die konsentriese sirkels:

- die familie van Ned Geref Kerke

- die drie Afrikaanse kerke

- ander Protestantse kerke

- die Rooms-Katolieke kerk

- sektariese en separatistiese groepe.

Die nabyheid van die sirkel sal die graad van intensiteit van die verhouding moet bepaal.

Hoe dit presies moet geskied is nie vir my om voor te skryf nie. Dit is die verantwoordelikheid van elke teoloog, kerkleier en lidmaat van die Christelike kerk in Suid-Afrika. Kreatiwiteit is wat ons moet bied - kom ons gee vorm daaraan in ons bediening. 


\section{SLOT}

Waarom is die eenheid van die kerk nodig - ja selfs noodsaaklik? Om by mekaar te leer en begrip te kry vir die rykdom van God se openbaring en sy genade en liefde. Sodoende kan ons mekaar help om 'n volle, en nie 'n verskraalde evangelie nie, te verkondig.

Dan ook as getuienis. Watter getuienis sal dit nie wees vir die hele wêreld as Suid-Afrika - 'n mikro-kosmos - sy probleme oplos nie. As die Christene in Suid-Afrika mekaar kan vind, kan dit wêreld wyd gebeur. Die verleentheid waarin Suid-Afrika en die Ned Geref Kerk hom tans wêreldwyd bevind, kan omskep word in 'n getuienisgeleentheid. Die wêreld se oë is op ons. Uit ons liefde vir mekaar sal hulle kan aflei of ons kinders van God is (Joh 13:35) en in die aanskoue daarvan, geinspireer word om self kinders van God te word.

Laastens bring die sigbare eenheid van die kerk die ervaring van die gemeenskap van die heiliges. Dit is die ervaring van 'n gemeenskaplike band wat sterker is as enige politieke, nasionale, rasse-, klasse- of ideologiese band. Dit is ook 'n bevrydende ervaring wat jou vrymaak om Christus en sy een kerk eerste te stel.

\section{NOTAS}

1. "Ons glo ..." Die drie Formuliere van Eenheid en Ekumeniese Belydenisse, Kaapstad 1982.

2. PB van der Watt, Die Nederduitse Gereformeerde Kerk, 1824-1905, Pretoria 1980, $76-7$.

3. Van der Watt, a $w, 1980,82-3$.

4. P B van der Watt, Die Nederduitse Gereformeerde Kerk, 1905-1975, Pretoria $1987,120$.

5. Inligting afkomstig uit 'n verslag van die Federale Sendingraad wat toe as die ekumeniese arm van die Ned Geref Kerk t o $v$ sending gedien het.

6. Van der Watt, a $w, 1987$.

7. EJ C Strassberger, Ecumenism in South Africa, 1936-1960, with special reference to the mission of the church, Johannesburg 1974, 324-377.

8. A G S Gous, "Die onvoltooide ekumeniese agenda", ISWEN-Kommunikasie vol 9:2 (Nov 1987), 3-26, en F E O'Brien Geldenhuys, "The dilemma of the Dutch Reformed church in South Africa", Optima vol 31 (1983), 158.

9. Die volledige besluite is te vinde in: A H Luckoff, Cottesloe, Kaapstad 1978.

10. Van der Watt, a w, 1987, 119-120.

11. J A Heyns, "Eenheid in Intemasionale perspektief: Isolasie deurbreek?!" Referaat gelewer te Pretoria: SEVTO, Universiteit van Pretoria, $1986,8$.

12. N J Smith, elkeen in sy eie taal, Pretoria 1980, 82-128 en D Crafford, Aan God die dank (1), Pretoria 1982, 61-463. (In 1976 is die naam verander na die Reformed Church in Africa.)

13. Kerk en Samelewing. 'n Getuienis van die Ned Geref Kerk, Bloemfontein 1986, 4243, par $246-50$.

14. T van der Walt, "Die eenheid van die kerk van Christus in Suid-Afrikaanse perspek- 
tief." Referaat gelewer te Pretoria: SEVTO, Universiteit van Pretoria, 1986, 1819.

15. Kerken Samelewing. 'n Getuienis van die Ned GerefKerk, Bloemfontein 1986, 44, par. 257-58.

16. Prof $\mathrm{CWH}$ Boshoff was tot en met sy aftrede 'n voorstander van die standpunt.

17. D J Bosch "Eenheid binne die 'familie' van Nederduitse Gereformeerde kerke waarheen?" Referaat gelewer te Pretoria: SEVTO, Universiteit Pretoria, 1986, 32.

18. Bosch, a w, 1986, 33. Die sendingkundige prof $D J$ Bosch is ' $n$ voorstander van hierdie standpunt.

19. D C Crafford, "Die Belydende Kring en ABRECSA en hulle invloed op kerklike verhoudinge in Suid-Afrika", Skrif en Kerk vol 7 (1986), 14.

20. Besluit 1.2.7, Handelinge 1975: 254.

21. Crafford, Skrif en Kerk vol 7 (1986), 21.

22. Crafford, Skrif en Kerk vol 7 (1986), 22.

23. Kerken Samelewing. 'n Getuienis van die Ned GerefKerk. Bloemfontein 1986, 44, par. 259.

24. P B van der Watt, "Eenheid in die Afrikaanse kerke. Referaat gelewer te Pretoria": SEVTO, Universiteit van Pretoria, 1986, 4-6.

25. Handelinge 1982 Algemene Sinode.

26. Aangehaal in Van der Watt a $w, 1986,5$.

27. Van der Watt a $w, 1986,6$.

28. Van der Watt a $w, 1986,7$.

29. Van der Watt a $w, 1986,8$.

30. SA Outlook, 1 Sept (1936), 203-208.

31. SA Outlook, 1 Aug (1940), 150-1.

32. CF A Borchardt, "Die Nederduitse Gereformeerde Kerk en die Suid-Afrikaanse Raad van Kerke", Skrif en Kerk vol 8 (1987), 1-19.

33. Cottesloe Consultation: Official Report, Johannesburg 1981, 84.

34. Borchardt, a $w, 1987,12-13$.

35. SACC: Minutes, 1975.

36. Borchardt, a w, 1987, 14-15.

37. Handelinge Algemene Sinode 1986, 99, 1188, 1065-6, 1329.

38. Borchardt, a w, 1987, 17.

39. Handelinge Algemene Sinode 1982, par 2.4.2.2.

40. Handelinge Algemene Sinode 1982, par 5.2.

41. P Rossouw, Ekumeniese Verkenning, Bloemfontein 1987, 64.

42. P Rossouw, a w, 1987, 67.

43. W D Jonker, "Eenheid van die kerk. Noodsaak of luukse." Referaat gelewer te Pretoria, SEVTO, Universiteit van Pretoria, 1986, 6 \& Bosch, a w,1986, 6.

44. Ter wille van volledigheid kan gesê word dat die Ned Geref Kerk die liberale teologie in ongeveer 1860 en met die Du Plessis-stryd rondom 1930 sogenaamd suksesvol "beveg" het, veral to $v$ die Skrifbeskouing en Christologie. Terselfdertyd het daar egter 'n liberale kerkbeskouing ingesluip - waarskynlik omdat dit polities so aantreklik was. (J HRoberts, "Wat is diekerk?" in: Eybers, I H; König, A \& Borchardt, CFA [reds] Teologie en Vernuwing, Pretoria 1975, 71.)

45. Tydens die paneelbespreking van die VTO-kursus oor die Eenheid van die Kerk, Universiteit Pretoria op 12/8/1986.

46. Roberts, a $w, 1975,74$.

47. PRossouw, "Die Ned Geref Kerk en die buitelandse kerke", in Van der Watt, PB (red) Die Ned Geref Kerk en sy Ekumeniese verhoudinge, Pretoria 1983, 69.

48. P G J Meiring, "Eksklusief of ekumenies?", in Venster op die Kerk. 20 lidmate oor die reformasie van die kerk in die jare 80, Potchefstroom 1980, 13-14. 